\title{
DETERMINATION OF URINARY OXALATE WITH ARYLAMINE GLASS-BOUND SORGHUM OXALATE OXIDASE AND HORSERADISH PEROXIDASE
}

\author{
M. Thakur ${ }^{1}$, A.K. Bhargava ${ }^{2}$ and C.S. Pundir ${ }^{3 *}$ \\ ${ }^{1}$ Department of Pathology, Dr B.R.Sur Homoeopathic Medical College \& Hospital, Nanakpura, New Delhi. \\ ${ }^{2}$ Department of Biochemistry, Jhalawar Medical College, Jhalawar, Rajasthan, India. \\ ${ }^{3}$ Department of Biochemistry, Maharshi Dayanand University, Rohtak-124001, Haryana, India \\ *Corresponding Author Email: pundircs@ rediffmail.com
}

\begin{abstract}
We describe an enzymic colourimetric method for determination of oxalate level in urine using arylamine glass-bound sorghum leaf oxalate oxidase and horseradish peroxidase. The method is based on quantification of $\mathrm{H}_{2} \mathrm{O}_{2}$ generated from oxidation of urinary oxalate by immobilized oxalate oxidase, by a colour reaction consisting of 4-aminophnazone, phenol and immobilized peroxidase as chromogen. Minimum detection limit of the method was $0.05 \mathrm{mmol} / \mathrm{l}$. Analytical recovery of added oxalate in urine was $96.8 \pm 3.0 \%$ (mean \pm S.D.). Within and between day coefficient of variation $(\mathrm{CV})$ for urinary oxalate in urine were $<3.5 \%$ and $<6.46 \%$ respectively. The urinary oxalate values in apparently healthy and urinary stone formers as measured by the present method were correlated with those by modified Sigma Kit method ( $r=0.929)$. The method has the advantages that it provides ca 200 times reuse of oxalate oxidase and peroxidase and free from interferences by $\mathrm{Cl}^{-}$and $\mathrm{NO}_{3}{ }^{-}$normally found in urine.
\end{abstract}

Keywords: Oxalate oxidase; peroxidase; arylamine glass beads; oxalate; urine

\section{Introduction}

Determination of oxalate in urine is essential for the diagnosis and medical management of various forms of hyperoxaluria, leading to urinary stone disease, malabsorption, steatorrhoea, illeal disease and ethylene glycol poisoning. The normal level of oxalic acid in urine is 20-30 mg/24h ((Hodgkinson, and Williams, 1972).Among the various methods available for determination of oxalate (Sharma et al.,1993; Pundir and Sharma,2010; Devi et al.,2013; Sithole et al.,2014), the enzymic colourimetric method employing oxalate oxidase and peroxidase is simple, sensitive, specific and requires only a colorimeter, therefore suitable for routine. However the method becomes expensive for a large number of samples, due to high cost of enzymes. Immobilization of enzyme(s) onto insoluble support allows its reuse and thus reduce the cost of the method. We have developed an enzymatic colorimetric method for determination of urinary oxalate using alkylamine glass bound sorghum leaf oxalate oxidase and horseradish peroxidase (Thakur and Pundir,1999). However, the immobilization of an enzyme onto alkylamine glass through glutaraldehyde has the disadvantage of extensive self-polymerization nature of glutaraldehyde and protein crosslinking and the support needs to be well washed prior to enzyme addition (Pundir et al, 1993a). Further the glutaraldehyde coupling involves Schiff's base formation, which has a drawback of reversibility of the reaction at low $\mathrm{pH}$ (Kennedy, 1975). Immobilization of an enzyme on arylamine glass through diazotization has no such problem, as it enables the inter-deposition of a spacer arm between two reduced steric interactions and yields higher enzyme to carrier conjugation ratio than by other coupling procedures (Foster, 1980). We have reported the immobilization of sorghum oxalate oxidase and horseradish peroxidase onto arylamine glass beads and studied their properties (Pundir et al; 1999a; Pundir et al;1999b ). The present report describes the method of urinary oxalate determination employing arylamine glass bound sorghum leaf oxalate oxidase and horseradish peroxidase and its evaluation.

\section{Material and Methods}

\section{Chemicals}

Zirconia coated arylamine glass beads (pore diameter 55 $\mathrm{nm}$ ) (Corning Glass Works, New York, USA), horseradish peroxidase $(\mathrm{RZ}=1.1)$, oxalic acid, 4-aminophenazone (Sigma Chemical Co., St.Louis, USA), DEAE-Sephacel 
and Sephadex G-200 (Pharmacia LKB Sweden). All other reagents were of analytical reagent grade.

\section{Collection of Plant Material and Purification of Oxalate Oxidase}

Ten day old seedling plants of grain sorghum hybrid (Sorghum vulgare var./genotype CSH-5) were raised in the laboratory and their leaves were collected as described in reference (Pundir and Nath,1984).The extraction and purification of oxalate oxidase from sorghum leaves was carried out by $80 \%$ ammonium sulphate precipitation, ion exchange chromatography on DEAE-Sephacel and Sephadex G-100 gel filtraion as described by Satyapal and Pundir(1993).The purified enzyme showed apparently single band in polyacrylamide gel electrophoresis, using coomassie blue as protein staining (Results not given ).

\section{Immobilization of Oxalate Oxidase}

Oxalate oxidase purified from sorghum leaves $(2.0 \mathrm{mg} / \mathrm{ml}$ 0.02M sodium phosphate buffer, $\mathrm{pH} 7.0$ ) was immobilized onto arylamine glass beads through diazotization according to reference (Pundir et al.,1999a).One hundred $\mathrm{mg}$ arylamine glass beads were taken in a $10 \mathrm{ml}$ conical flask kept on ice bath. One $\mathrm{ml}$ chilled $2 \mathrm{~N} \mathrm{HCl}$ and $25 \mathrm{mg}$ solid $\mathrm{NaNO}_{2}$ were added to the flask. The diazotization reaction in flask was allowed to proceed for $30 \mathrm{~min}$ in cold. The diazotized beads were washed several times with $0.1 \mathrm{M}$ sodium phosphate buffer, $\mathrm{pH} 7.0$ to remove excess of acid until $\mathrm{pH}$ of the washing discard was 7.0.One ml of purified enzyme was added to these activated /diazotized beads and the flask was kept at $4^{0} \mathrm{C}$ for $48 \mathrm{hr}$ with occasional stirring for immobilization. The enzyme/protein bound to glass beads was estimated by determining the loss of protein from the decanted enzyme solution using Lowry method.

\section{Immobilization of Peroxidase}

Commercially available horseradish was dissolved in $0.05 \mathrm{M}$ sodium phosphate buffer $(\mathrm{pH} 7.0)(4.0 \mathrm{mg} / \mathrm{ml})$ immobilized on arylamine glass beads through diazocoupling according to reference (Pundir et al,1999b) as described above.

\section{Preparation of Standard Curve for Oxalate with Immobilized Oxalate Oxidase and Peroxidase}

In a $10 \mathrm{ml}$ conical flask wrapped with black paper, the reaction mixture containing $85 \mu \mathrm{mol}$ of sodium phosphate buffer ( $\mathrm{pH}$ 6.0), $1.0 \mu \mathrm{mol}$ of $\mathrm{CuSO}_{4}$ and mixture of $100 \mathrm{mg}$ each of arlyamine glass beads coupled to sorghum oxalate oxidase and horseradish peroxidase, were preincubated at $45^{\circ} \mathrm{C}$ for $5 \mathrm{~min}$. The reaction was started by adding varying the concentration of oxalate in the range, $0.10-1.0 \mathrm{mM}$ in a total volume of $2.0 \mathrm{ml}$. After incubation at $45^{\circ} \mathrm{C}$ for $5 \mathrm{~min}$, $1.0 \mathrm{ml}$ of color reagent (consisting of $50 \mathrm{mg} \mathrm{4-}$ aminophenazone and $100 \mathrm{mg}$ solid phenol in $100 \mathrm{ml} 0.4 \mathrm{M}$ sodium phosphate buffer, $\mathrm{pH}$ 7.0), was added to the flask and kept at room temperature $\left(30 \pm 2^{\circ} \mathrm{C}\right)$ for $10 \mathrm{~min}$ to develop pink colour. The flask was tilted, the beads were allowed to settle down on the side wall of flask and the reaction mixture was transferred carefully into the cuvette with the help of Eppendorf pipette. $A_{520}$ was read in Spectronic-20. A standard curve was plotted between oxalate concentration vs. A 520 (Fig.1).

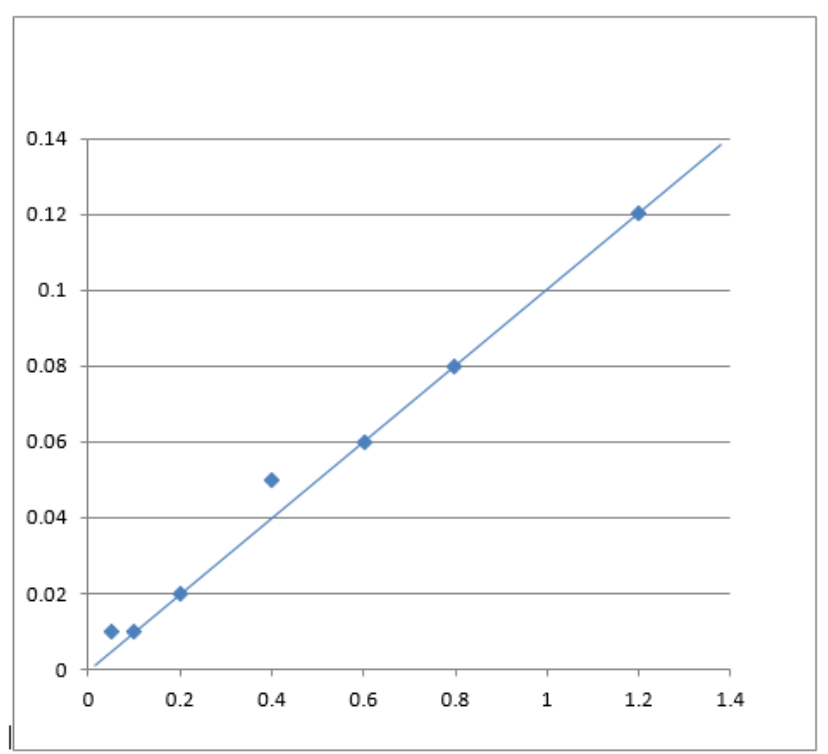

Fig. 1: Standard curve between oxalate concentrations vs A 520 using arylamine glass bound sorghum leaf oxalate oxidase and arylamine glass bound horseradish peroxidase

\section{Determination of Urinary Oxalate}

\section{Sample collection and pre-treatment}

$24 \mathrm{hr}$ urine samples were collected from healthy individuals of different age groups in $2 \mathrm{~L}$ plastic bottles containing 15 $\mathrm{ml}$ conc. $\mathrm{HCl}$. Acidied urine samples were diluted with an equal amount of $0.1 \mathrm{M}$ potassium phosphate buffer $(\mathrm{pH} 7.0)$ and the $\mathrm{pH}$ of urine sample was adjusted between 5-7 by adding $\mathrm{NaOH}$ drop wise. To avoid possible ascorbate interference, $0.1 \mathrm{ml}$ buffered $\mathrm{NaNO}_{2}(35 \mathrm{mg} / 10 \mathrm{ml} 0.1 \mathrm{M}$ sodium phosphate buffer, $\mathrm{pH} 7.0$ ) was added to $1 \mathrm{ml}$ diluted urine (Satyapal and Pundir, 1993).

\section{Assay of urinary oxalate}

It was carried out as described for preparation of standard curve of oxalate except that oxalic acid solution was replaced with $0.1 \mathrm{ml}$ pretreated urine. The value of oxalate in urine was extrapolated from the standard curve between oxalic acid concentrations vs. A 520 (Fig. 1).

\section{Evaluation of Method of Urinary Oxalate Determination}

The following criteria were studied to evaluate the method:

\section{Limit of detection (LOD)}

LOD of the method was considered as the concentration of oxalate at which $\mathrm{A}_{520}$ was 0.01 .

\section{Analytical recovery}

To determine the analytical recovery of the method, solid oxalate $(20 \mathrm{mg}$ and $30 \mathrm{mg} / \mathrm{L})$ was added to pretreated urine samples and oxalate content in urine was determined before 
and after addition of oxalate. The percent recovery of added oxalate was calculated.

\section{Precision}

To study precision, the oxalate content was determined in six urine samples repeatedly on the same day (Within batch) and then after their storage at $-20^{\circ} \mathrm{C}$ for one week. The within and between day coefficient of variation $(\mathrm{CV})$ were calculated for urinary oxalate determination.

\section{Correlation}

To determine the accuracy of the method, the oxalate content in urine samples was determined by standard enzymic colorimetric method of Sigma with slight modification(x) and the present $\operatorname{method}(\mathrm{y})$ and the values were correlated by regression equation.

\section{Reuse of Arylamine Glass Bead Bound Oxalate and Peroxidase}

Arylamine glass beads bound to oxalate oxidase and peroxidase were washed off with the reaction buffer 3-4 times prior to use in their next assay. During each washing, the buffer was withdrawn by Eppendorf pipette carefully avoiding the loss of glass beads. The beads were stored in distilled water at $4^{\circ} \mathrm{C}$ when not in use.

\section{Results and Discussion}

An oxalate oxidase purified from the leaves of 10- day old seedling plants of grain sorghum hybrid ( $\mathrm{CSH}-5$ ) has been immobilized onto arylamine glass through diazo-coupling with a conjugation yield of $9.2 \mathrm{mg} / \mathrm{g}$, which is better than that for barley enzyme on the same support $(6.63 \mathrm{mg} / \mathrm{g})$
(Pundir et al,1999a). The enzyme retained $34.1 \%$ of its initial specific activity after immobilization. Commercially available horseradish peroxidase was also immobilized separately onto arylamine glass with a congugation yield of $18.0 \mathrm{mg} / \mathrm{g}$ and $60 \%$ retention of its initial specific activity (Pundir et al., 1999b).

The arylamine glass-bound oxalate oxidase showed maximum activity at $\mathrm{pH} 5.5$, when incubated at $45^{\circ} \mathrm{C}$ for 5 min. The immobilized enzyme was unaffected by $\mathrm{Cl}^{-}$(as $\mathrm{NaCl}$ ) and $\mathrm{NO}_{3}^{-}$(as $\mathrm{NaNO}_{3}$ ) both at $1 \mathrm{nM}$ and their respective physiological concentration (Pundir 1999a). Earlier immobilized oxalate oxidase from other sources were found sensitive towards $\mathrm{Cl}^{-}$and $\mathrm{NO}_{3}{ }^{-}$concentrations normally found in urine. These results showed the better suitability of sorghum enzyme than that from other sources for oxalate determination (Table1).The arylamine conjugated horseradish peroxidase exhibited maximum activity at pH 7.5 on incubation at $40{ }^{\circ} \mathrm{C}$ for $15 \mathrm{~min}$ (Pundir et al., 1999b).

A new method for determination of urinary oxalate was developed employing mixture of arylamine glass bound sorghum oxalate oxidase and horseradish peroxidase. The method is based upon measurement of $\mathrm{H}_{2} \mathrm{O}_{2}$ generated from oxidation of urinary oxalate by immobilized sorghum oxalate oxidase. This $\mathrm{H}_{2} \mathrm{O}_{2}$ was measured by Trinder's colour reaction, where immobilized peroxidase was employed in place of free peroxidase, which catalyzes the oxidation of $\mathrm{H}_{2} \mathrm{O}_{2}$ and conjugation of 4-aminophenazone with phenol. The resulting pink quinoneimine dye is measured at $520 \mathrm{~nm}$.

Table 1: Effect of $\mathrm{Cl}^{-}$(as $\mathrm{NaCl}$ ) and $\mathrm{NO}_{3}{ }^{-}$(as $\mathrm{NaNO}_{3}$ ) on plant oxalate oxidase immobilized on various supports

\begin{tabular}{llll}
\hline Plant & Support & Property & Reference \\
\hline Barley Seedlings & Nylon tubing & Inhibition by $\mathrm{Cl}^{-}$ & Potezny et al [18] \\
& Collagen membrane & Interference by $\mathrm{Cl}^{-}$ & Saka Amini\& Vallon [19] \\
& Gelatin & Interference by $\mathrm{Cl}^{-}$ & Dinkaya \& Telefoncu [12] \\
& Alkyamine glass & Inhibition by $\mathrm{Cl}^{-}$ & Pundir et al [11] \\
\hline Banana peel & Immune complex & $66 \%$ inhibition by $\mathrm{Cl}^{-}$ & Inamdar et al [10] \\
\hline Beet stem & Polyethylene glycol & Inhibition by $\mathrm{Cl}^{-}$ & Varalakashmi et al [20] \\
\hline Sorghum leaf & Arylamine glass & No inhibition by $\mathrm{Cl}^{-}$and $\mathrm{NO}_{3}^{-}$ & Present \\
(Present work) & & & \\
\hline
\end{tabular}


We studied the following analytic parameters for evaluation of the method

\section{Minimum Detection Limit}

The minimum detection limit of the present method was $0.05 \mathrm{mmol} / \mathrm{L}$, which is similar to the earlier method using alkylamine glass-bound oxalate oxidase and peroxidase (Thakur and Pundir, 999) and comparable to other methods employing barely oxalate oxidase immobilized to gelatin (0.1 mmoles/L) (Dinckaya and Telefoncu, 1993), polyamide membrane (0.1 mmoles/L) (Assolant et al., 1987) and pig intestine membrane $(0.1 \mathrm{mmoles} / \mathrm{L})$ (Rahni and Guibault, 1986).

\section{Recovery Studies}

The reliability of the method was checked by performing recovery test in urine samples. The analytical recovery of added oxalate $(20 \mathrm{mg} / \mathrm{L}$ and $30 \mathrm{mg} / \mathrm{L})$ in urine samples was $96.5 \pm 1.2 \%$ (mean \pm S.D.) and $94.1 \pm 2.2 \%$ (mean \pm S.D.) respectively by the present method (Table 2), which is similar to that using sorghum and barely enzyme immobilized onto alkylamine glass beads (recovery $96.5 \%$ and 96.8\%) (Pundir et al., 1993b), (Thakur, and Pundir, 1999), on pig intestine membrane (93.5\%-106.5\%) (Rahni and Guibault, 1986), on nylon tubing (95.9\%) (Bais et al, 1980) and AF tresyl toyopearl gel (95.5\%) (Yamato et al, 1994).

Table 2: Analytical recovery of added oxalate in urine as determined by arylamine glass-bound sorghum oxalate oxidase and horseradish peroxidase

\begin{tabular}{|c|c|c|}
\hline $\begin{array}{l}\text { Oxalate added } \\
(\mathrm{mg} / \mathrm{L})\end{array}$ & $\begin{array}{l}\text { Mean oxalate } \\
\text { value } \\
(\mathrm{mg} / \mathrm{L}) \\
(\mathrm{n}=6)\end{array}$ & $\begin{array}{l}\text { \% recovery } \\
(\text { Mean } \pm \\
\text { S.D. }) \\
(n=6)\end{array}$ \\
\hline Nil & 16.2 & - \\
\hline 20 & 34.5 & $96.5 \pm 1.2$ \\
\hline 40 & 43.65 & $94.1 \pm 2.2$ \\
\hline
\end{tabular}

\section{Precision}

To check the reproducibility and reliability of the method, the oxalate content in the same urine sample in one run (within batch) and after one week storage at $20^{\circ} \mathrm{C}$ (between assay) were determined. The results showed that the oxalate values in the same samples agreed with each other and within \& between batch coefficients of variation were $<3.6 \%$ and $<5.85 \%$ respectively (Table 3 ). These results are comparable with earlier reported methods using sorghum enzyme immobilized onto alkylamine glass (3.5\% for within batch and $<6.46 \%$ for between batch) (Pundir et al, $1993 b)$, barley oxalate oxidase immobilized to nylon tubing (2.0\% for intrabatch and $<7.0 \%$ for interbatch) (Bais et al., 1980), pig intestine membrane mounted on the tip of $\mathrm{O}_{2}$ electrode (C.V. 3.2\% -5.16\%) (Rahni and Guibault, 1986) and tresyl toyopearl gel (5.3\% for intrabatch and $7.9 \%$ for interbatch) (Yamato et al., 1994).
Table 3: Within and between assay coefficients of variation (CV) for determination of urinary oxalate by arylamine glass-bound sorghum oxalate oxidase and horseradish peroxidase.

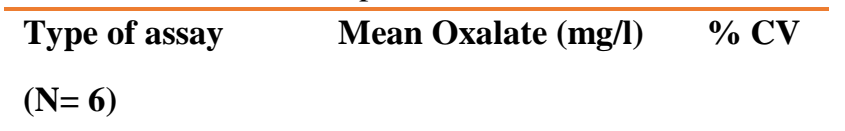

\begin{tabular}{l|l|l}
\hline Within assay* & 27.4 & $<3.6$ \\
\hline Between Assay*** & 26.6 & $<5.85$ \\
\hline & \\
\hline *sample assayed on the same day \\
** Same samples were assayed after one-week storage at $-20^{\circ} \mathrm{C}$
\end{tabular}

\section{Accuracy}

To evaluate the accuracy of the method, we compared the oxalate values of 15 urine samples as determined by the Sigma Kit method (x) with modifications and by the present method (y). A good correlation $(r=0.929)$ was obtained with the regression equation being $\mathrm{y}=0.99 \mathrm{x}+(0.0077)$ for a mean oxalate concentration of $34.3 \mathrm{mg} / 24 \mathrm{~h}$, which is comparable to earlier method using alkylamine glass-bound sorghum oxalate oxidase and horseradish peroxidase ( $\mathrm{r}=0.9234)$ (Thakur, and Pundir, 1999).

\section{Interference Study}

To study the interference of various urinary substances on the immobilized enzymes, the following substances were added to the reaction mixture, each at a final concentration of $1 \mathrm{mM}: \mathrm{Na}_{2} \mathrm{CO}_{3}, \mathrm{NaHCO}_{3}, \mathrm{NaCl}, \mathrm{KCl}, \mathrm{MgSO}_{4}, \mathrm{Na}_{2} \mathrm{SO}_{4}$, $\mathrm{MnCl}_{2}, \mathrm{CdCl}_{2}, \mathrm{CuSO}_{4}, \mathrm{BaCl}_{2}, \mathrm{FeSO}_{4}, \mathrm{NiSO}_{4}, \mathrm{ZnSO}_{4}$, pyruvate, urea, glycine, glutamate, citrate, glucose, fructose, and creatinine. These results as given in Table 4. Of these substances tested, $\mathrm{CuSO}_{4}$ caused two-fold stimulation of immobilized oxalate oxidase. Rest of the compounds had practically no effect. NADH and ascorbate caused strong inhibition of colour reaction catalyzed by peroxidase but not the reaction of oxalate oxidase. Interference by ascorbate in both enzymic and non-enzymic methods for determination of urinary oxalate is well known (Bias et al, 1980). Various methods for elimination of ascorbate interference in urinary oxalate determination by oxalate oxidase have been suggested, such as pretreatment of urine with $\mathrm{NaNO}_{2}, \mathrm{NaIO}_{4}, \mathrm{FeCl}_{3}$, charcoal, alumina, ascorbate oxidase and selective precipitation of oxalate as its calcium salts( Inamdar et al., 1987). They also compared the efficiencies of five of these ascorbate eliminating methods and found that the pre-treatment with $\mathrm{FeCl}_{3}, \mathrm{NaIO}_{4}$ or $\mathrm{NaNO}_{2}$ was $90 \%$ effective with low concentrations of ascorbate in the urine, while charcoal and ascorbate oxidase treatments were $100 \%$ effective with high concentrations of ascorbate in urine. In the present work, the urine was pretreated with buffered $\mathrm{NaNO}_{2}$ for elimination of ascorbate interference (Inamdar et al., 1991). 
Table 4: Effect of various substances on the activity of arylamine glass bound sorghum oxalate oxidase

\section{Compound added}

Relative activity

(\%)

\begin{tabular}{ll}
\hline None & 100.0 \\
\hline $\mathrm{Na}_{2} \mathrm{Co} 3$ & 90.0 \\
\hline $\mathbf{N a ~ H C O} 3$ & 90.0 \\
$\begin{array}{l}\mathbf{N a C l}(\mathbf{5 0} \mathbf{~ m M}, \mathbf{1 0 0} \mathbf{~ m M , ~ 2 5} \\
\mathbf{m M})\end{array}$ & $100.0,100.0,100.0$ \\
\hline
\end{tabular}

\begin{tabular}{lc}
$\mathrm{KCl}$ & 100.0 \\
$\mathrm{MgSO}_{4}$ & 100.0 \\
$\mathrm{Na}_{2} \mathrm{SO}_{4}$ & 100.0 \\
$\mathrm{MnCl}_{2}$ & 100.0 \\
Urea & 100.0 \\
\hline
\end{tabular}

Glycine $\quad 100.0$

\begin{tabular}{lc} 
NADH & 20.0 \\
\hline Ascorbate & 10.0 \\
CuSO4 & 125.0 \\
Pyruvate & 100.0
\end{tabular}

\begin{tabular}{lc|} 
Glutamate & 90.0 \\
\hline Citrate & 110.0 \\
\hline Glucose & 90.0 \\
\hline Fructose & 110.0 \\
Creatinine & 100.0
\end{tabular}

Standard assay conditions were used except for the addition of compound indicated at a final concentration of $1.0 \mathrm{mM}$ in the reaction mixture. $\mathrm{NaCl}$ also tested at additional concentration of $50 \mathrm{mM}, 100 \mathrm{mM}$ and $250 \mathrm{mM}$.

\section{Measurement of Urinary Oxalate}

The oxalate value in $24 \mathrm{~h}$ urine collected from apparently healthy individuals of different age and sex were measured by the present method using immobilized oxalate oxidase and peroxides and were found in the range 11.0-41.5 mg/24 $\mathrm{h}$ (mean $19.0 \mathrm{mg} / 24 \mathrm{~h}, \mathrm{n}=46$ ) (Table 5). The mean values of urinary oxalate determinations by our enzyme are comparable to those obtained by barley oxalate oxidase immobilized onto alkylamine glass beads $(19.8 \mathrm{mg} / 24 \mathrm{hr})$ (Pundir et al., 1993b) and immune complex of banana oxalate oxidase (17.17 mg/24hr) (Inamdar et al., 1991).
Table 5: Oxalate values in urine samples of healthy individuals and urinary stone patients as determined by arylamine glass bound sorghum oxalate oxidase and horseradish peroxidase

\begin{tabular}{|c|c|c|c|c|}
\hline \multirow{2}{*}{$\begin{array}{l}\text { Age } \\
\text { groups } \\
\text { (years) }\end{array}$} & \multirow[t]{2}{*}{ Sex } & \multirow{2}{*}{$\begin{array}{l}\text { Number of } \\
\text { samples } \\
\text { analyzed }\end{array}$} & \multicolumn{2}{|c|}{ Oxalate values $(\mathrm{mg} / \mathrm{L})$} \\
\hline & & & $\begin{array}{l}\text { Healthy } \\
\text { individual } \\
\text { (Mean } \\
\pm \text { S.D.) }\end{array}$ & $\begin{array}{l}\begin{array}{l}\text { Stone } \\
\text { formers }\end{array} \\
\text { (Mean } \pm \\
\text { S.D.) }\end{array}$ \\
\hline \multirow[t]{2}{*}{$10-30$} & M & 8 & $17.05 \pm 1.2$ & $32.37 \pm 2.8$ \\
\hline & $\mathrm{F}$ & 8 & $15.5 \pm 1.5$ & $35.7 \pm 3.6$ \\
\hline \multirow[t]{2}{*}{$31-50$} & M & 6 & $19.0 \pm 1.7$ & $36.4 \pm 3.3$ \\
\hline & $\mathrm{F}$ & 8 & $19.4 \pm 1.9$ & $39.4 \pm 3.0$ \\
\hline \multirow{2}{*}{$\begin{array}{l}50 \text { and } \\
\text { above }\end{array}$} & M & 8 & $21.37 \pm 1.5$ & $38.35 \pm 3.6$ \\
\hline & $\mathrm{F}$ & 8 & $21.41 \pm 2.0$ & $31.6 \pm 2.6$ \\
\hline
\end{tabular}

\section{Reusability and Storage of Arylamine Glass Bead Bound Oxalate Oxidase and Peroxidase}

Arylamine glass bound oxalate oxidase and peroxidase lost $20 \%$ of its initial activity during its regular use for about 200 times, when stored in distilled water at $4^{\circ} \mathrm{C}$.

Arylamine glass bound sorghum oxalate oxidase and horseradish peroxidase were used about 200 times without any considerable loss of activity in the present method. Since the enzymes are the most expensive component of the commercial kit method, the use of glass bound enzymes would definitely reduce the cost of determination of oxalate in a large number of urine samples and thus method has an economic advantage. Further the use of immobilized sorghum oxalate oxidase in the method does not require pretreatment of urine for removal of $\mathrm{Cl}^{-}$and $\mathrm{NO}_{3}{ }^{-}$prior to oxalate assay. The method could also be applied to hyperoxaluric patients and stoneformers to analyze high oxalate concentration because of its wide range from 0.05 $\mathrm{mmol} / \mathrm{l}$ to $1.2 \mathrm{mmol} / \mathrm{l}$. The method does not require any specialized equipment except that of a colorimeter, which is inexpensive and easy to operate. Hence the method is expected to be more suitable for developing countries, where the clinical laboratories are not well equipped.

\section{Acknowledgment}

One of the authors, Manisha Thakur is grateful to Council of Scientific and Industrial Research (CSIR) New Delhi for the award of Senior Research Fellowship (SRF) during the tenure of the present study. The seeds of grain Sorghum var.CSH-5(used in the present study) were gift from M/s Nath Seeds Pvt. Ltd. Aurangabad, Maharasthra, India 


\section{References}

Assolant CH, Bardeletti G and Couplet PR (1987) A novel membrane electrode for oxalate determination. Anal. Lett. 20:513-527. DOI: $10.1080 / 00032718708067985$

Bias R, Potezny N, Edward JB, Rofe AM and Conyers RAJ (1980) Oxalate determination by immobilized oxalate oxidase in a continuous flow system Anal. Chem. 52:508-511. DOI: 10.1021/ac50053a030

Devi R, Relhan S and Pundir CS (2013) Construction of a chitosan/polyaniline/graphene oxide nanoparticles/polypyrrole/Au electrode for amperometric determination of urinary/plasma oxalate Sens. Acuat. B. Chem.186:17-26. DOI: 10.1016/j.snb.2013.05.078

Dinckaya E and Telefoncu A (1993) Enzyme electrode based on oxalate oxidase immobilized in gelatin for specific determination of oxalate. Ind. J. Biochem. Biophys. 30:.282-284.

Foster RL (1980) Modification of enzyme activity. In: Baron PJ and Jarret RJ (Eds) The nature of Enzymology, Croom helm Ltd. London, 93-161.

Hodgkinson A and Williams A (1972) An improved colorimetric procedure for urinary oxalate. Clin. Chim. Acta 36:127132. DOI: 10.1016/0009-8981(72)90167-2

Inamdar KV, Raghavan KG and Pradhan DS (1991) Five treatment procedures evaluated for the elimination of ascorbate interference in enzymatic determination of urinary oxalate. Clin. Chem. 37: 864-868.

Kennedy JP (1975) Principle of immobilization of enzymes. In: Handbook of Enzyme Biotechnology. Wiseman A (Eds) second edition 394, Ellis Harwood Ltd, Chichester, U.K. 380-417.

Pundir CS and Nath R (1984) Occurrence of oxalate oxidase in Sorghum leaves. Phytochemistry. 23: 1871-1874. DOI: 10.1016/S0031-9422(00)84932-8

Pundir CS and Sharma M (2010) Oxalate biosensors: A review $J$. Sc. Indust. Res. 69: 489-494.

Pundir CS, Kuchhal NK and Satyapal (1993a) Barley oxalate oxidase immobilized onto zirconia coated alkylamine glass beads. Ind. J. Biochem. Biophys. 30: 54-57.
Pundir CS, Malik V, Bhargava AK, Thakur M, Kalia V, Singh S, Kuchhal NK (1999b) Studies on horseradish peroxidase immobilized onto alkylamine and arylamine glass. J. Plant Biochem. Biotechnol. 8:123-126. DOI: 10.1007/BF03263073

Pundir CS, Thakur M, Goyal L, Bhargava AK (1999a) Immobilization of sorghum leaf oxalate oxidase onto alkylamine and arylamine glass. Chinese J. Biotechnol. 15: $129-138$.

Pundir CS, Satyapal and Kuchhal NK (1993b) Immobilization of barley oxalate oxidase onto alkylamine glass for determination of urinary oxalate. Cin. Chem. 39:599-601.

Rahni MANand Guilbault GG (1986) Immobilized enzyme electrode for the determination of oxalate in urine. Anal. Chem. 58: 523-526. DOI: 10.1021/ac00294a005

Satyapal and Pundir CS (1993) Purification and properties of an oxalate oxidase from leaves of grain sorghum hybrid CSH5. Biochem. Biophys. Acta. 1161: 1-5. DOI: 10.1016/01674838(93)90188-W

Sharma M, Thakur M, Chandran P and Pundir CS (2000) Determination of oxalate in food stuffs by oxalate oxidase immobilized to alkylamine glass beads affixed inside a beaker. J. Plant. Biochem. Biotechnol. 9: 41-43. DOI: 10.1007/BF03263098

Sharma S, Nath R and Thind SK (1993) Recent advances in measurement of oxalate in biological fluids.Scan.Micro.7:431-441

Sithole BB, Azeez AM and Ramjugernath D (2014) A new method for the analysis of soluble and insoluble oxalate in pulp amd paper matrices J. Wood Chem. Technol. 34: 55-66. DOI: $10.1080 / 02773813.2013 .827210$

Thakur M and Pundir CS (1999) Determination of urinary oxalate with alkylamine glass bound sorghum oxalate oxidase and horseradish peroxidase. Biotechnol. Techniques.13: $227-$ 230. DOI: $10.1023 / \mathrm{A}: 1008938311020$

Yamato S, Wakabayashi M, Nakajima M and Shimada K (1994) Amperometric determination of oxalate in plasma and urine by liquid chromatography with immobilized oxalate oxidase J. Chromatogr. 656: 29-35. DOI: 10.1016/03784347(94)80020-0 